FEATURE

\title{
Securing the nation's infrastructure: The Ohio River
}

\author{
Lois Wright Morton and Kenneth R. Olson
}

$\mathrm{T}$ raders, explorers and early settlers of the American West traveling the Ohio River from Pittsburgh, Pennsylvania, to the Mississippi River eagerly awaited the river's seasonal rises and flooding. Late fall rains in October through November and spring rains and winter snowmelt from the Appalachian Mountains signaled the river would soon rise above its rocky bottom and flood the Falls of the Ohio at Louisville, Kentucky (figure 1), enabling navigation. The trip up and down the Ohio River in all seasons was a dangerous adventure with river flows blocked and diverted by fallen trees, floating logs, and rocks. Some summers the water levels were so low that boats were grounded and horse drawn wagons easily crossed the river, and in winter the frozen waters brought all navigation to a halt (Olson and Morton 2016).

The Ohio River was and is today a critical transportation artery connecting the East Coast and the Midwest. An economic driver of the region and nation, this inland waterway carries raw materials, agricultural commodities, and finished products used within the United States and exported to countries around the world. It is used by municipalities, industries, fishers, recreational boaters, birdwatchers, and naturalists that value the river ecosystem for its water and wildlife resources. To realize the vision of a reliable navigation depth, the US Army Corps of Engineers (USACE) was authorized by the US Congress in 1824 to make the river more navigable. Tree and snag removal and the construction of dikes and wing dams were early efforts to improve the river flow and deepen the main channel. Almost 200

Lois Wright Morton is professor emeritus of sociology in the College of Agriculture and Life Sciences, lowa State University, Ames, lowa, and Kenneth R. Olson is professor emeritus of soil science in the Department of Natural Resources and Environmental Sciences, College of Agricultural, Consumer, and Environmental Sciences, University of Illinois, Urbana, Illinois.

\section{Figure 1}

Prior to construction of a canal and locks near Louisville, Kentucky, the rocks and rapids of the Falls of the Ohio limited navigation and required portage of passengers and freight up and down-river on this section of the Ohio River. Today these unique limestone rocks and fossils are protected by the McAlpine Dam (background) and can be viewed from the Clarksville, Indiana, side of the river.

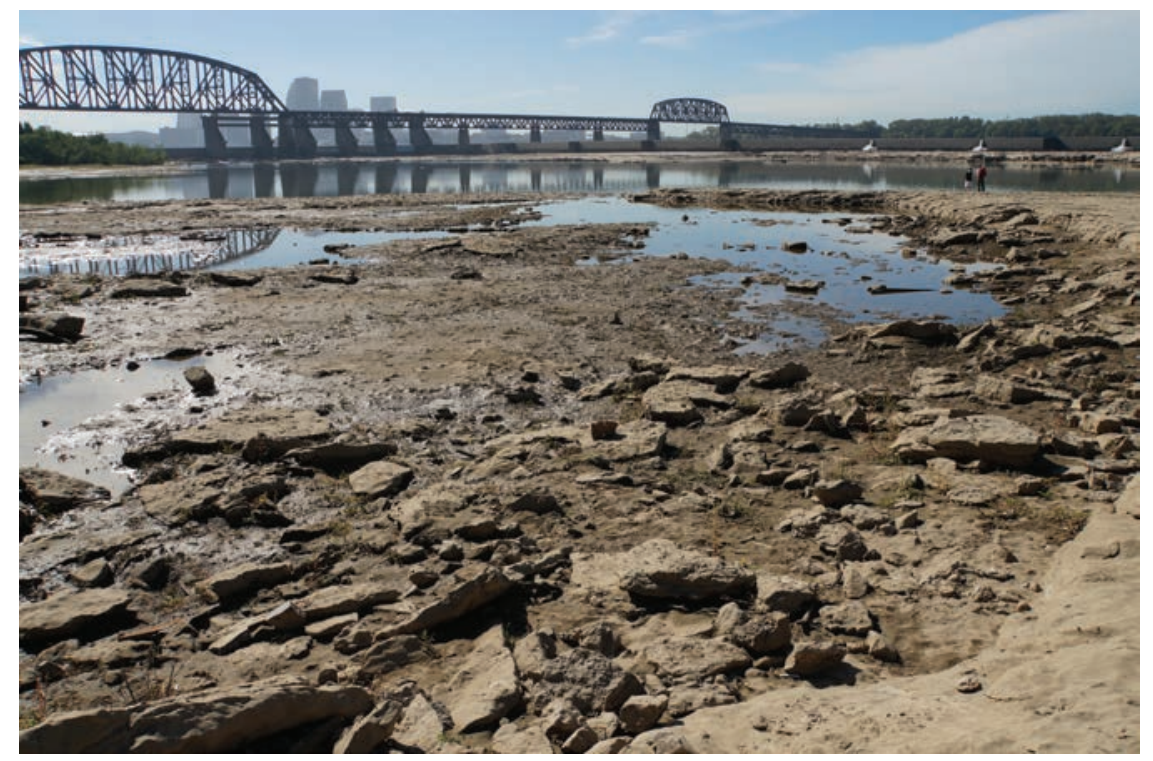

years later, USACE Colonel Antoinette Gant, at the 2018 dedication of the stateof-the art Olmsted Locks and Dam (figure 2 ), recalled the days when "keelboat operators stopped their vessels and carried goods on mules around areas of low water and when paddle wheelers stopped in the river because the navigation channel disappeared" (Gant 2018). The construction of the first canal and locks around the Falls of the Ohio near Louisville was completed in 1830. This engineering marvel and early river technology made navigation an allseason possibility and was one of the first public investments to create and maintain reliable channel depths. Today the USACE manages the Ohio River and its $137 \mathrm{~m}$ (450 $\mathrm{ft}$ ) elevation drop from Pittsburgh to the Ohio-Mississippi river confluence using 20 locks and dams (figure 3). In October of 2018, the new Olmsted Locks and Dam replaced both locks and dams no. 52 and no. 53 reducing the total number of locks and dams on the Ohio. The USACE con- tinues to modernize river infrastructure and redefine river navigation with goals to concurrently keep the economy moving and growing; better manage river flooding of adjacent agricultural lands, small towns, and cities; and protect the wetlands and biodiversity of the river ecosystem.

\section{THE ANCIENT OHIO RIVER AND THE CACHE RIVER VALLEY}

The Ohio River is the main tributary stream of the Mississippi River. Flowing southwest from the Appalachian uplands, it was formed between 2.5 and 3 million years ago when glacial ice dammed segments of north flowing rivers. About 625,000 years ago, the ancient Ohio River, fed by the Green and Cumberland rivers of Kentucky, flowed through the modern-day Cache River basin in southern Illinois to its confluence with the ancient Mississippi several kilometers (miles) northwest of the present-day Cairo confluence (Olson and Morton 2014; Cache 
River Wetlands Center 2013). During this period, the Wabash River of Indiana was not yet formed, and the ancient Tennessee River flowed in the main channel of the modern-day lower Ohio River. As the climate warmed, the glaciers melted and the high volumes of sediment carried by the ancient Ohio were deposited in the Cache River basin. The river became a slow-moving stream, and the ancient Ohio River shifted into its present course (Esling et al. 1989). Today the Ohio River runs along the borders of six states (figure 3) from Pittsburgh, Pennsylvania, in the northeast to the Mississippi River confluence at Cairo, Illinois, and drains land east of the continental divide.

\section{OHIO RIVER BASIN}

The Ohio River basin drains 14 states (figure 4) encompassing 528,358 $\mathrm{km}^{2}$ $\left(204,000 \mathrm{mi}^{2}\right)$ and carries the largest volume of water of any tributary of the Mississippi River. Home to nearly 25 million people, the river basin has a unique ecological system and is a social, political, and economic force (Olson and Morton 2016). Formed by the confluence of the Allegheny and Monongahela rivers at Pittsburgh, Pennsylvania, the Ohio runs almost 1,570 km (981 mi) before it converges with the Mississippi River at Cairo, Illinois. Hundreds of tributaries (figure 4) flow from the eastern Appalachian uplands into the Ohio River.

The seasonal drought and flood cycles of the Ohio are products of topography, weather, and climate. Historically, the river waters dropped to a depth of $30 \mathrm{~cm}$ (12 in) in an exceptionally dry summer or experienced overbank flooding and an 18.1 $\mathrm{m}(60 \mathrm{ft})$ crest when spring thaw coincided with storms that dropped their loads over the Ohio River valley. Heavy winter snows, fast spring melts, and heavy precipitation did little damage to the Ohio River pre-industrial landscape. As steamboats replaced keelboats and flatboats in the 1820 s and the population grew, unreliable river depths became a drag on economic potential. Coal barges and steamboats were often grounded in port cities waiting for a high water surge before they could navigate southwest (Castro 2009). In 1875 Congress allocated funds for small dams

\section{Figure 2}

The Olmsted Locks and Dam on the Ohio River, opened to river traffic in 2018, has twin $364 \mathrm{~m}$ locks that can move $1.36 \times 10^{8} \mathrm{t}$ of cargo annually with capacity to handle increased river tonnage into the future.

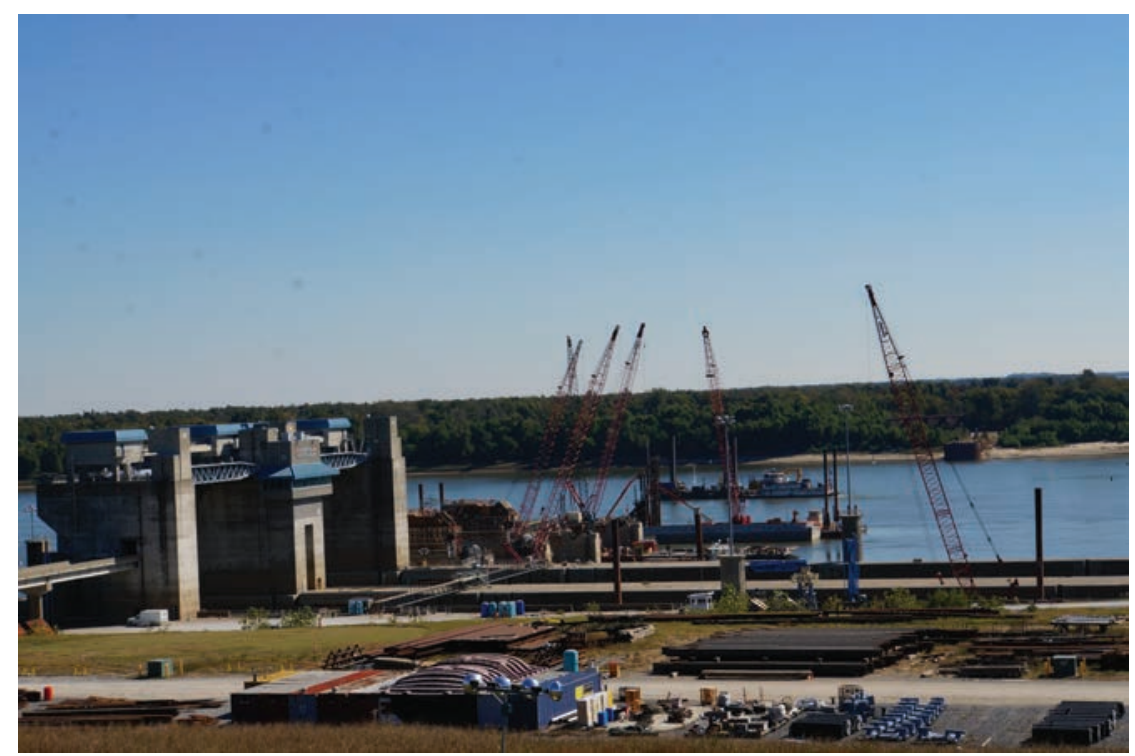

\section{Figure 3}

The 1950 S Ohio River Navigation Modernization Program systematically replaced 51 wooden wicket dams and lock chambers with 20 locks and dams to maintain a 2.7 $\mathrm{m}$ channel navigation. Map drawn by Mic Greenberg.

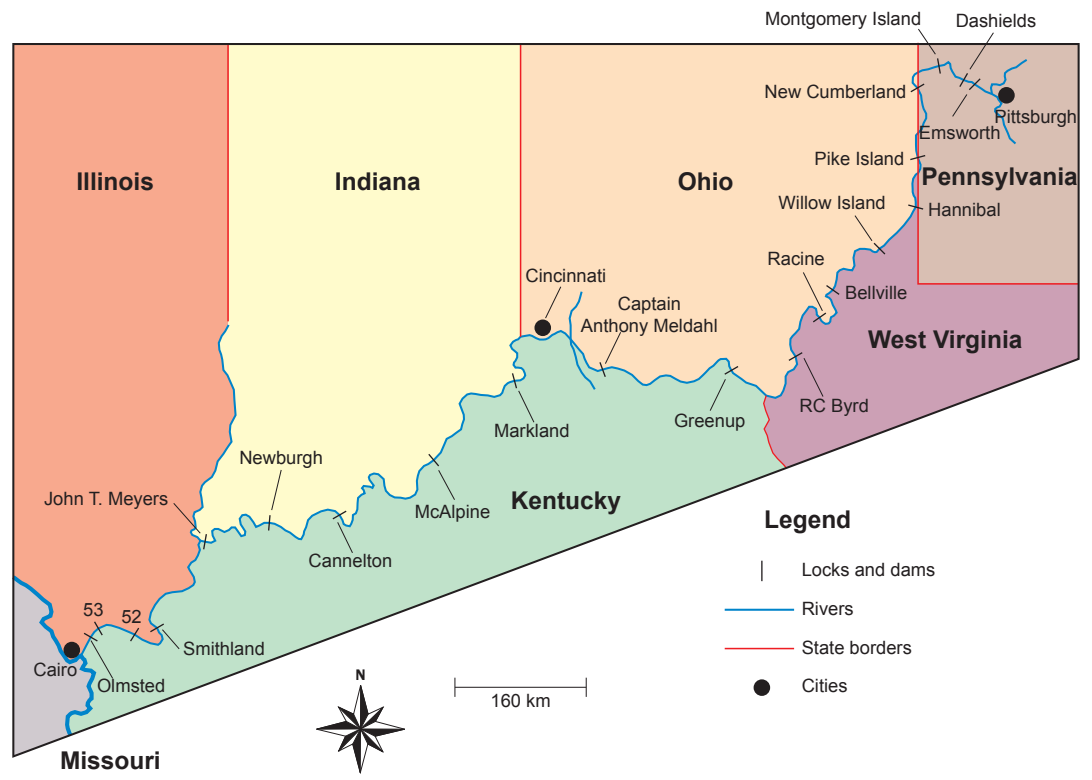

within the riverbed to create a $1.8 \mathrm{~m}(6 \mathrm{ft})$ deep channel (Welky 2011).

While drought affects navigation, flooding poses the greatest threat to river cities and their populations and industries. A series of flood events in the Ohio
River valley in the 1800 s and early 1900 s revealed the increased vulnerability of the region with the growth in river settlements and industrialization (Welky 2011). In the flood of 1937, a natural disaster of unprecedented proportions, nearly 400 


\section{Figure 4}

The Ohio River watershed encompasses land and reservoirs in 14 eastern states and their tributaries draining westward from the Appalachian uplands. Map drawn by Mic Greenberg.

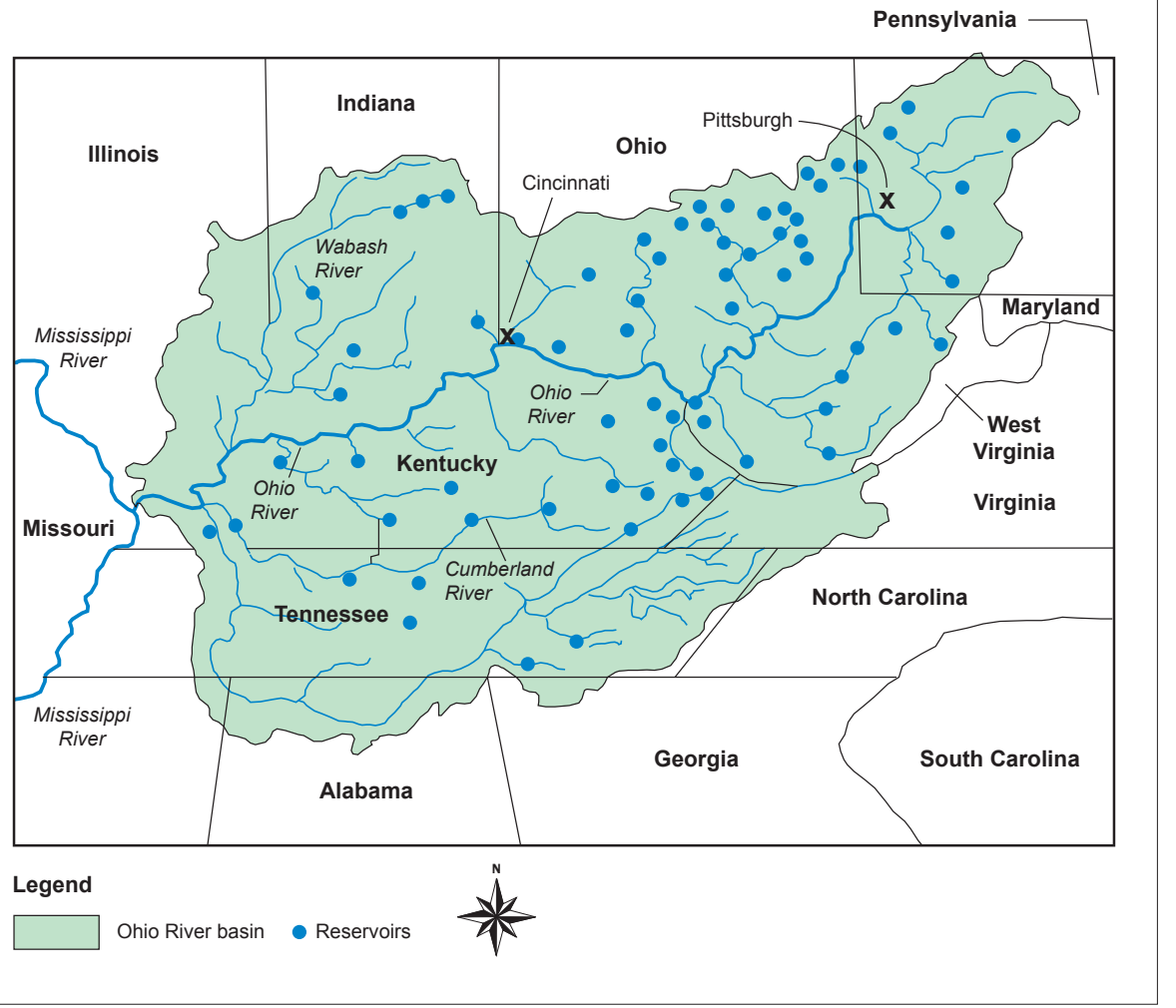

people lost their lives, a million people were displaced from their homes, and a record US $\$ 500$ million in damages occurred (Castro 2009). Flood Control Acts of 1936 and 1938 were the beginning of a national flood control policy that coordinated efforts to construct floodwalls, levees, and upstream storage reservoirs to protect the economic security of the Ohio and Mississippi river basins.

\section{ALLEGHENY RIVER}

The Allegheny River is the primary tributary of the Ohio River, and local American Indian tribes considered it part of the Ohio River. The Allegheny is $523 \mathrm{~km}$ (325 mi) long and joins the Monongahela River to officially form the Ohio River at Point State Park in downtown Pittsburgh, Pennsylvania (figure 5). The Allegheny River basin is $30,000 \mathrm{~km}^{2}\left(11,580 \mathrm{mi}^{2}\right)$. Its watershed in western Pennsylvania has extensive deposits of coal, petroleum, and natural gas, making the valley one of the most productive fossil fuel extraction areas in the United States. The word Allegheny can be translated as "best flowing river of the hills" or "beautiful stream."

The Allegheny River has eight locks and dams, which are numbered two to nine. The river is impounded by the Kinzua Dam in northwest Pennsylvania creating the Allegheny Reservoir. The dam provides regional flood control and generates hydroelectric power by pumping water to the Seneca Pumped Storage Generating Station reservoir above the dam. A number of bridges and tunnels span the river including the Allegheny River Tunnel used by Pittsburgh light rail since 2012.

\section{MONONGAHELA RIVER}

The Monongahela River in southwestern Pennsylvania, eastern Maryland, and north central West Virginia is $209 \mathrm{~km}$ (130 mi) long with a 19,011 $\mathrm{km}^{2}\left(7,340 \mathrm{mi}^{2}\right)$ basin (Monongahela Navigation Company 1937). The watershed is $160 \mathrm{~km}(100 \mathrm{mi})$ at its widest point. Winding through the valleys of the Appalachian Mountains, the river's elevation reaches $340 \mathrm{~m}(1,100 \mathrm{ft})$ above sea level at times. The average discharge rate is $358 \mathrm{~m}^{3} \mathrm{~s}^{-1}\left(12,650 \mathrm{ft}^{3} \mathrm{~s}^{-1}\right)$.

During the Wisconsinan glaciation (110,000 to 10,000 years ago) the Monongahela River flowed north across present-day Pennsylvania and New York State and into the St. Lawrence River basin. Lake Monongahela, created by a huge ice dam, formed a body of water that stretched from present-day Beaver, Pennsylvania, for $320 \mathrm{~km}$ (200 mi) to present-day Weston, West Virginia.

The Pennsylvania legislature in 1817 authorized the Monongahela Company to create a river transportation system by the construction of 16 dams with bypass locks. The Monongahela River was used by mining industries and a number of US Steel plants in the 1800s. A canal tunnel constructed in 1832 through Grant's Hill in Pittsburgh enabled boats to travel between the Monongahela River and the Western Division Canal of Pennsylvania. This became a main route for east-west canal and railroad traffic.

\section{NAVIGATION ON THE OHIO RIVER PRIOR TO 1824}

When explorer Meriwether Lewis left Pittsburgh, Pennsylvania, and started down the Ohio River in 1803, the water depth was very low. It was a dry year, and navigation was difficult. Farmers stood on the riverbank ready to rent out their team to boat owners to pull the boats over the wide, but shallow, rocky stream. Like other travelers on the Ohio River, Lewis encountered the Great Falls of the Ohio (figure 1) near Louisville, Kentucky. These limestone ledges made the river impassable from midsummer through early winter, delaying downriver trips or requiring portaging of boats and cargo around the falls (Welky 2011). Steamboats could only guide their boats over the falls when the water was high, which was not predictable. As a result, passengers and freight were dropped off on one end of the falls and transported overland to the opposite end of the falls to another steamboat. Louisville became the last stop for vessels on both sections of the Ohio River. With growth in river traffic, it soon became apparent that some type of canal and lock system was needed to circumvent the falls if steamboats and other 


\section{Figure 5}

The Ohio River is formed at the confluence of the Monongahela and Allegheny rivers at Pittsburgh, Pennsylvania.

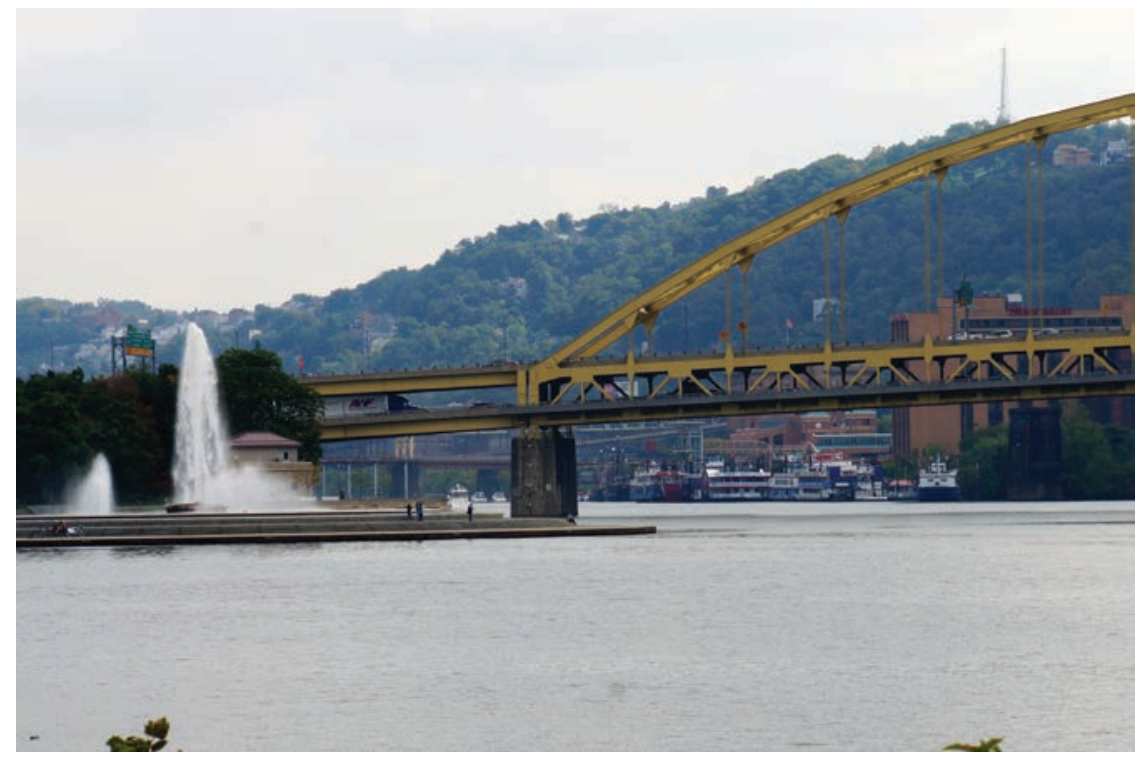

river vessels were to avoid delays and travel unimpeded though the falls area without waiting for high water.

\section{OHIO RIVER INLAND WATERWAY}

In 1825 construction began on a canal around the Falls of Ohio and was completed in 1830 (figure 1). Privately financed by Louisville and Portland Canal Company, it was constructed using hand labor and animal-drawn scrappers and carts. When finished, the canal measured $3 \mathrm{~km}$ (2 mi) long and had three locking chambers that enabled a total lift of 8 $\mathrm{m}(26 \mathrm{ft})$. Steamboat travel on the Ohio River benefited from the canal as navigation on the Ohio River became possible year around, even in droughts. This new infrastructure spurred river travel, making it a preferred passenger and shipping route to the west.

Coal tonnage shipped down the Ohio River from Pittsburgh increased greatly after the Civil War (1861 to 1865). The length of tows used to push and pull the wooden barges increased as powerful steam towboats had more capacity to move bigger loads. Due to the escalating coal trade, the USACE began to search for new methods to manage navigation depths on the Ohio River. After launching an international study and gathering data on other navigation projects of other countries, the Corps decided that a lock and dam system could solve the problem.

\section{WICKET DAMS AND LOCKS}

Downstream from Pittsburgh, Davis Island became the first USACE lock and dam on the Ohio River. Opened for use in 1885, it improved navigation and substantively increased passenger and commercial river traffic. Twenty-five years later, Congress passed the Rivers and Harbors Act, which provided authorization to deepen the navigation depth to $2.7 \mathrm{~m}(9 \mathrm{ft})$ by constructing a system of lock and dams the entire length of the Ohio River. The project was completed in 1929. The new system had 51 wooden wicket dams and lock chambers, $182 \mathrm{~m}$ (600 ft) by $33.5 \mathrm{~m}$ $(110 \mathrm{ft})$. The wicket dams created pools of deeper water to maintain navigation depth in the main channel when the river was low. The locks enabled vessels to bypass the dams when the river levels were low, and the wickets could be lowered when the river was high so vessels did not need to use the locks.

The wicket dam and lock system moved millions of tons of goods throughout the United States during World War II. Dieselpowered towboats replaced steam engines in the 1940s and increased the capacity of tows to pull and push barges that were longer than the $182 \mathrm{~m}$ (600 ft) locks. This led to the hazardous and time-consuming practice of "double locking." One 15-barge tow now had to be separated into two groups of barges plus the tow boat, thus requiring two locking procedures. This often delayed other barge and boat traffic waiting to lock through and increased costs to the towing industry. It soon became clear that the lock and dam system needed longer locks. The Ohio River Navigation Modernization Program, begun in the 1950s, enabled the USACE to systematically replace the outdated wicket dams and small locks with 20 larger locks and dams (figure 3). A reengineering of the dams using steel and concrete made them permanently nonnavigable. One $5.5 \mathrm{~m}$ (18 ft) dam replaced two or three of the wicket dams. Most newly designed dams had two adjoining locks (one 182 by $33.5 \mathrm{~m}$ [600 by $110 \mathrm{ft}]$ and one 364 by $33.5 \mathrm{~m} \mathrm{[1,200 \textrm {ft }}$ by $110 \mathrm{ft}]$ ), which could hold 15 barges and allow them to lock through in one maneuver. The Smithland Locks and Dam (figure 3) was built with two $364 \mathrm{~m}(1,200 \mathrm{ft})$ chambers. The 2009 McAlpine Locks and Dam at Louisville created a second $364 \mathrm{~m}$ $(1,200 \mathrm{ft})$ lock, widened the canal to $152 \mathrm{~m}$ (500 ft), and increased the lift to $11.3 \mathrm{~m} \mathrm{(37}$ ft) to accommodate increasing barge traffic.

\section{LOCK AND DAM POOL HABITAT}

The river level is regulated by USACE, and the navigation channel is marked by buoys the entire length of the Ohio River. Water depths in the channels range from $2.7 \mathrm{~m}$ (9 $\mathrm{ft})$ to $27 \mathrm{~m}(90 \mathrm{ft})$. The pool areas behind the locks and dams, embankments, and open river areas provide diverse habitats for wetland vegetation, birds, and fisheries. Over 150 different species of fish have been recorded on the Ohio River. The smaller pools and open river areas provide anglers opportunities to catch channel catfish, blue catfish, flathead, striped bass, hybrid striped bass, and white bass.

Across from the McAlpine Locks and Dam at Louisville is the Falls of the Ohio Interpretive Center where visitors can walk on the limestone river rocks that grounded so many steamboats (figure 1).A protected wetland area, the center features outdoor and indoor fossil and mineral labs 
and opportunities to search for fossils and learn about the geology, flora, and fauna of the river ecosystem.

\section{THE FLOOD OF 1937 ON OHIO RIVER}

Spring rains and melted ice and snow that pour into the mountain gullies and creeks and bloat the Ohio River instill the greatest fear into river communities. During periods of heavy rainfall and snowmelt, the runoff from nearby hillsides turns the Ohio River into a raging torrent that can sweep away everything in its path. The growth of cities along the river, the river's natural flood cycle, and extreme rain events over the region have made the Ohio River basin vulnerable to natural disaster. Pittsburgh has had more than 80 floods over a period of 84 years (Welky 2011). The worst was in late 1936

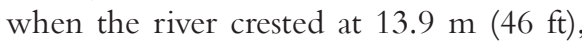
the downtown was under $6.1 \mathrm{~m}(20 \mathrm{ft})$ of water, and 54 people died. Almost every city along the Ohio River has a flood history. Major Ohio River floods are documented in 1862, 1883, 1884, 1901, 1907, 1913, and 1937. Since 1937, subsections of the river experienced record flooding in 1945, 1997, and 2011 (Castro 2009; NOAA 2013). More recently, after days of heavy rain in February of 2018, the river at Cincinnati, Ohio, rose $3.7 \mathrm{~m} \mathrm{(12} \mathrm{ft)} \mathrm{above}$ flood stage and inundated downtown. Flooding was not confined to Cincinnati, and the Ohio governor declared a state of emergency for the 17 counties adjacent to the Ohio River (Remington 2018).

The flood of 1937, called by Welky (2011) a thousand-year flood, was one of the worst disasters to strike the Ohio River valley. A four-week storm cycle iteratively ravaged the region as two huge weather systemswarm, moist air from the Gulf of Mexico flowing northward and dry polar air from the northwest - collided and dumped rain on frozen ground causing heavy runoff into upstream tributaries of the Ohio River. The first storm began December 25, 1936, and continued into the first few days of 1937 when it dropped $18 \mathrm{~cm}$ (7 in) of rain on the Tennessee River basin.

These sequential storms intensified tributary overflow, stacked the water on top of itself, and created multiple crests on the Ohio River (Welky 2011; Castro
2009). With the Ohio River many meters (feet) above flood stage, tributaries could not drain and backed up into surrounding lowlands. By the fourth week of storms, river cities protected by floodwalls realized that even if their floodwall held, the river was likely to come over the wall.

The 1937 flood destroyed many of the railroads throughout the Ohio River valley and severed telegraph and communications. This disastrous flood only compounded the human and economic toll the region already was experiencing from the Great Depression. Poor and black families were hit the hardest. They lived and worked in the flood-prone lower sections of the river cities, lost what few belongings they had, and experienced discriminatory treatment in rescue operations, disaster aid, and temporary resettlement (Welky 2011). Postflood, community leaders, engineers, and the federal government recognized the need to be more proactive in preventing these disasters and began to make flood control investments in levees, floodwalls, and storage reservoirs to better manage river flooding. The Flood Control Act of 1938 redefined the role of government for planning, financing, and operating flood control structures.

\section{MANAGING THE OHIO RIVER BASIN TO REDUCE FLOODING}

Over the years, many hundreds of reservoirs were built on the tributaries of the Ohio River (figure 4). Flood control was often the main reason for dam construction. Most of these dams were built in the 1900 s on tributaries, but none were on the main stem of the Ohio River, which was used for navigation. The reservoirs store flood waters and allow for controlled release during drought to help maintain river depths. Most dams were constructed from one valley wall to another and blocked a stream, creek, or river. The soils covered with river water were floodplain soils and bottomland soils. Often the prior land use was either wetlands or agricultural land, and any cities and towns, including cemeteries, had to be moved.

\section{MANAGING THE OHIO RIVER BASIN} FOR NAVIGATION AND FLOOD CONTROL

For many years river navigation and flood control were considered separate issues competing for local and national resources, with navigation given the highest priority on the Ohio River. President Franklin Roosevelt envisioned his New Deal construction project, the Tennessee Valley Authority (TVA), as an opportunity to develop a nationally coordinated, watershed-based rivers policy that encompassed planned flood control, hydroelectric power, and improved land management (Welky 2011). While the TVA never replaced the role of the USACE in managing the Ohio River, dams and reservoirs on Ohio River tributaries became valuable sources of hydropower while effectively controlling water levels to maintain shipping channels and store flood waters for slow release (Olson and Morton 2016). Since the construction of the Kentucky Dam on the Tennessee River in the 1940s and the Barkley Dam in 1960s on Cumberland River, the USACE has had the ability to store water and release it during droughts to maintain a minimum depth

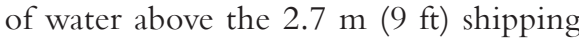
channel (Olson and Morton 2016). The water release also increases the flow in the lower Mississippi River. During the 2012 drought, the USACE was able to add $1.0 \mathrm{~m}(3.3 \mathrm{ft})$ to the existing flow, which reduced the need for dredging.

The most strategic section of the Ohio River is the segment that connects the Ohio, Tennessee, Cumberland, and Mississippi rivers. A bottleneck here can back barge traffic up for many kilometers (miles). The port of Paducah, Kentucky, located on this reach is known as the hub of the Ohio and Mississippi rivers waterway system. All barge traffic moving between the Mississippi River system and the Ohio, Tennessee, and Cumberland rivers must pass thorough this area. In 2011, over $9.14 \times 10^{7} \mathrm{t}\left(9 \times 10^{7} \mathrm{tn}\right)$ of goods were transported through this section of the Ohio River.

\section{SECURING THE NATION'S INFRASTRUCTURE: OLMSTED LOCKS AND DAM}

The USACE role in providing a safe and efficient navigation infrastructure on the Ohio River is a mission without an end. The 20 locks and dams in 2013 (figure 4) 
were reduced to 19 in October of 2018 when the Olmsted Locks and Dam (figure 2) came on line.This state-of-the art infrastructure replaces the last of the old wicket dams, locks and dams no. 52 and no. 53, on the lower Ohio near Paducah, Kentucky, and Olmsted, Illinois. These locks and dams will be removed during the next two years. Located at river mile 964.4 $\left(37.1838^{\circ} \mathrm{N}, 89.0635^{\circ} \mathrm{W}\right), 27 \mathrm{~km}(17 \mathrm{mi})$ upstream from the Ohio-Mississippi river confluence, Olmsted greatly reduces tow and barge delays and shortens navigation time from four to five hours to one hour. The dam consists of five Tainter gates, a $425 \mathrm{~m}(1,400 \mathrm{ft})$ navigable passage with steel wicket gates, and fixed weir. In the raised position, the wickets maintain the required navigation depths from Olmsted upstream to Smithland Locks and Dam. When river flows are high, the wickets can be dropped to lie flat on the bottom of the river.This permits river traffic to travel over the dam sill rather than use the locks and reduces delays associated with locking through or waiting in line to lock through. The lock chambers, completed in 2002 and located along the Illinois bank, are $33 \mathrm{~m}(110 \mathrm{ft})$ wide and $364 \mathrm{~m}(1,200$ ft) long (USACE 2012). The capacity of Olmsted is projected to meet growth in tow traffic demands well into the twentyfirst century.

An Olmsted engineering innovation that created controversy was the "in-thewet" construction method. Traditional techniques require temporary dams, called "cofferdams" to create a large dry space around the work site so the dam cells can be poured in place. In 2004, the lock portions of the project were built behind traditional cofferdams. However, the "inthe-wet" method was used to cast dam sections on the Illinois bottomlands and then lug them overland, using the "super gantry" crane (figure 6) to the river for placement using smaller cranes. The super gantry crane had to be built on site and can lift up to 4,812 t (5,304 tn).

Another innovation was "self-consolidating concrete," a new concrete placement technique, which won the 2015 Innovation of the Year award for the Olmsted engineering team. A third new technology was the use of computer

\section{Figure 6}

A super granty crane was used to lift pre-formed cement frames to the Ohio River for positioning in the riverbed to construct the Olmsted Locks and Dam.

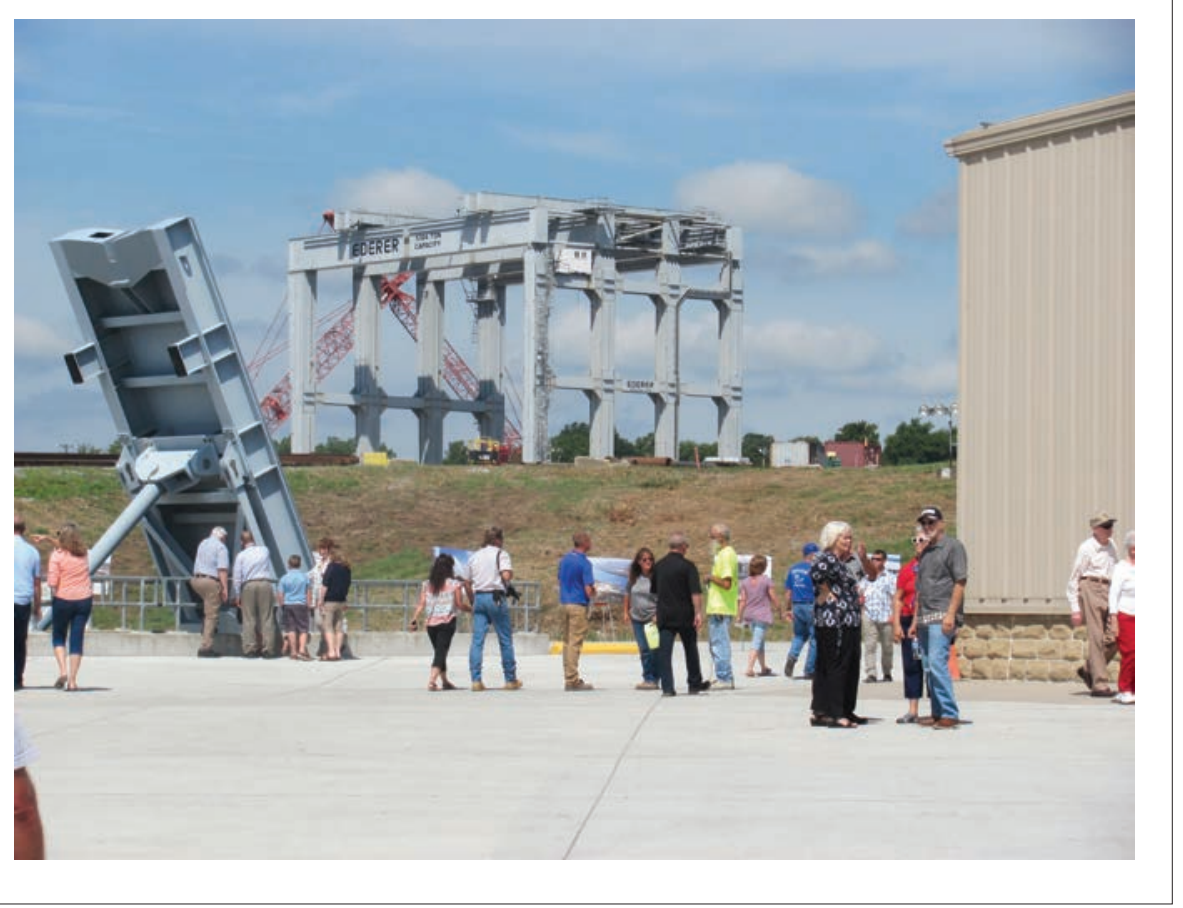

modeling built on the rapid advances in processing power, which can also be used in other USACE projects.

\section{RIBBON CUTTING AT THE OLMSTED LOCKS AND DAM CEREMONY}

The Olmsted Locks and Dam was authorized by the US Congress on November 17, 1988, with the passage of the Water Resources Development Act of 1988 (Public Law 100-676). Construction began in 1995. The cost of the project is shared by congressional appropriation and the navigation industry. Industry pays a tax on diesel fuel, initially US $\$ 0.05 \mathrm{~L}^{-1}$ $\left(\mathrm{US} \$ 0.20 \mathrm{gal}^{-1}\right.$ ) and currently at US $\$ 0.08$ $\mathrm{L}^{-1}\left(\mathrm{US} \$ 0.29 \mathrm{gal}^{-1}\right)$, which goes into the Inland Waterways Trust Fund. The trust fund pays half of the project costs.

The Olmsted Locks and Dam completion was celebrated with a ribbon cutting ceremony on August 30, 2018, at Olmsted, Illinois. There were about 250 dignitaries present, plus 250 police and military and about 500 visitors, including past employees. The speakers included the Secretary of the Army, Mark Esper; the Assistant Secretary of the Army, R.D. James; the leader of the Senate, Mitch McConnell
(Kentucky); and the Democratic Whip, Richard Durbin (Illinois).

The group of dignitaries pressed a large red button to signal the lock master to sound the horn and the lock gates opened. The tow of the Glenn W. Jones of American Commercial Barge Line entered the lock, breaking the gigantic red ribbon and marking the first ceremonial lockage. Although USACE leaders and partners worked out a funding plan to speed up completion of the construction, Olmsted ended up costing four times as much as initially estimated and took six times as long to complete. This US $\$ 2.7$ billion project utilized numerous engineering innovations and was given priority in the USACE budget for over 30 years.

The Olmsted Locks and Dam project had a huge economic impact on southern Illinois and Kentucky. Between 1996 and 2018, thousands of union workers were employed to build the locks and dam structure. The project had a positive effect on the livelihoods of people living in the region and ensures safe and efficient Ohio River navigation between Smithville and Cairo into the future. Paducah, the hub of Ohio River traffic, is expanding its port facilities. 


\section{CONCLUSION}

The Ohio River basin covers a large geographic area of the United States east of the Mississippi River. It extends northeast into New York, west to Illinois, and south, encompassing the drainage basins of the Tennessee River in Kentucky, Tennessee, Georgia, Alabama, and Mississippi. An early gateway to the west for adventurers, entrepreneurs, and settlers, the river today is a critical transportation infrastructure for moving grains, coal and ores, and other raw commodities as well as manufactured products. The Ohio and its navigable tributaries move about $2.54 \times 10^{8} \mathrm{t}\left(2.80 \times 10^{8}\right.$ tn) of cargo yearly, more than the annual tonnage through the Panama Canal (Gant 2018). River transport of bulk goods and commodities is less expensive than by rail or commercial trucks.

The economic, social, and ecological footprint of this inland waterway affects the livelihoods of millions of people. The movement to basin-wide management has enabled local and federal agencies to proactively manage the river and its tributaries for navigation, flood control, hydropower, and water supply. With the advent of scientific management investments in better maps; surveys of the river and reservoir sites; increased gaging stations; and better data on weather, land use, and erosion conditions, the USACE, local port authorities, and partners have improved navigation and flood control decision making.

The Ohio River between Smithland, Kentucky, and Cairo, Illinois, has the most shipping of any section of the US inland waterways maintained by lock and dam systems. The Department of Homeland Security recognizes the Ohio River lock and dam infrastructure as an essential resource that needs to be secure, maintained, and modernized. The construction of the Olmsted Locks and Dam utilized new river technologies and redefined modern river navigation. The USACE estimates the annual net benefits of the completed Olmsted project at US $\$ 640$ million per year. While this is a remarkable strengthening of the navigation infrastructure, it will be necessary to continuously invest in the safety and efficiency of the entire inland water system. Any national infrastructure bill passed by the US
Congress needs to recognize and include inland waterway projects in addition to highways, airports, and bridges. The ports and other structures on the Ohio River must be maintained and updated to ensure year-round transport of domestic and international goods.

Lastly, navigation is only one function of the Ohio River. River communities and their industries derive enormous other benefits from the river but also present challenges in land uses, water degradation, and river ecosystem wellbeing. Renewed efforts and investments are needed to protect lives and resources against flooding and river disasters. Better understanding of the river ecosystem is necessary if we are to develop complementary solutions to protecting river and wetland systems and address the difficult and complex problems associated with growing populations and increased pressures on river resources.

\section{ACKNOWLEDGEMENT}

Published with funding support from USDA National Institute of Food and Agriculture, Water Division; the director of the Illinois Office of Research, College of Agricultural, Consumer, and Environmental Science, University of Illinois, Urbana, Illinois; and the Iowa Agriculture and Home Economics Experiment Station, College of Agriculture and Life Sciences at Iowa State University, Ames, Iowa.

\section{REFERENCES}

Cache River Wetlands Center. 2013. Cache River

- State Natural Area. Springfield, IL: Illinois Department of Natural Resources. http://dnr. state.il.us/lands/landmgt/parks/r5/cachervr.htm.

Castro, J.E. 2009. The Great Ohio River Flood of 1937. Charleston, SC:Arcadia Publishing.

Esling, S.P., W.B. Hughes, and R.C. Graham. 1989 Analysis of sediment properties with the Cache Valley, southern Illinois and implications regarding the late Pleistocene-Holocene development of Ohio River. Geology 17:434-437.

Gant, A.R. 2018. Olmsted Locks and Dam, Securing the Nation through Infrastructure. August 30th, 2018 dedication. Louisville District, US Army Corps of Engineers.

Monongahela Navigation Company (1840-1897). 1937. The Darlington Collection. Pittsburgh, PA: University of Pittsburgh.

NOAA (National Oceanic and Atmospheric Administration). 2013. Historic crests. Morris, IL:
National Weather Service, Advanced Hydrologic Prediction Service.

Olson K.R., and L.W. Morton. 2014. The 2011 Ohio River flooding of the Cache River Valley in southern Illinois. Journal of Soil Water Conservation 69(1):5A-10A, doi:10.2489/ jswc.69.1.5A.

Olson, K.R., and L.W. Morton. 2016. Managing Mississippi and Ohio River Landscapes. Ankeny, IA: Soil and Water Conservation Society.

Remington, K. 2018. Kasich issues emergency for 17 Ohio counties. The Plain Dealer, February 25.2018. USACE (US Army Corps of Engineers). 2012. The Upper Mississippi River nine-foot channel navigation project. The US Waterway System Transportation Facts and Information. Alexandria, VA: Navigation and Civil Works Decision Support Center.

Welky, D. 2011. The Thousand-year Flood: The Ohio-Mississippi Disaster of 1937. Chicago, IL: University of Chicago Press. 